\title{
The Australian Priest-Penitent Privilege: Are They Protected?
}

\author{
Patrick van Esch ${ }^{1} \&$ Linda Jean van Esch ${ }^{2}$ \\ ${ }^{1}$ School of Law, Charles Darwin University, Northern Territory, Australia \\ ${ }^{2}$ Western Australian School of Mines, Faculty of Science \& Engineering, Curtin University, Perth, Australia \\ Correspondence: Patrick van Esch, School of Law, Charles Darwin University, Ellengowan Drive, Casuarina, \\ NT 0810, Australia. Tel: 61-8-8946-6666. E-mail: vesch54@hotmail.com
}

Received: August 5, 2013 Accepted: August 23, 2013 Online Published: November 29, 2013

doi:10.5539/jpl.v6n4p90 URL: http://dx.doi.org/10.5539/jpl.v6n4p90

\begin{abstract}
In Australia, the extent of the priest-penitent privilege has received much attention recently due to the appointment of a Royal commission into institutional responses to child sexual abuse in 2012. At present, only five (5) Australian jurisdictions provide statutes for some form of privilege to protect certain types of communications between clerics and individuals. The other jurisdictions rely on case law where it is deemed that the priest-penitent privilege does not apply, but this belief is yet to be tested. In an attempt to abide by their religious laws, and depending on the their particular denomination, clerics may be entitled, not obliged to refuse divulging subject matter from religious confessions, even if a confession was made or not.
\end{abstract}

Keywords: priest-penitent privilege, the evidence acts, religious law, professional communications privilege, case law, state law, cleric

\section{Introduction}

With the sanctity of the confessional being challenged in an increasingly secular world, it is becoming more likely that a religious cleric may be called to give evidence in a court of law; irrespective of any understanding towards the cleric's ethical and religious obligations. The religious laws of churches (i.e. Anglican and Catholic) prevent their clerics from revealing what is disclosed from a formal confession, even if the cleric is called as a witness and legally obliged in a court of law (Maybe, 2006).

The Evidence Acts of the Commonwealth, New South Wales, Victoria, Tasmania and the Northern Territory have an inclusion for priest-penitent privilege. However, the privilege provided by the statutes does not always provide the protection clerics or penitents expect as it is restricted to ritual confession. Common law principles apply for the balance of the other Australian jurisdictions and although the case law is not clear, it is widely accepted that there is no privilege at common law for clerics or penitents (Maybe, 2006). Religious law (i.e. laws of the church) and the laws of the state lack in compatibility. State laws may not always provide protection for the clerics, yet where there is protection, the state(s) provide to the penitent no greater protection than the church already gives.

\section{Unfounded Information}

One argument is that the rule against hearsay would exclude from evidence any statements made in a ritual confession, however it is not the case because the rule against hearsay evidence "prevents witnesses from repeating statements made out of court in order to prove the truth of those statements" (Waight and Williams, 2002: 598; Maybe, 2006). Noting the many exceptions to the hearsay rule, in civil cases; the truth of statements of admission by a party to those proceedings can be admitted as evidence of hearsay (Maybe, 2006). In criminal cases, confessions can be admitted as evidence of the truth of such confessions. Whilst a religious 'confession', may fall within one of the exceptions to the hearsay rule; it is often considered a confession at law (Maybe, 2006).

\subsection{Does It Count?}

If a witness claims legal privilege in a tribunal and/or court of law, it enables them to refuse revealing information and/or communications (Maybe, 2006); even if such information/communications is relevant to the trial (McNicol, 1992). However, where legal privilege exists; it is considered limited and such situations to be anomalies of the law (Note 1). 


\subsection{The Evidence Act}

Only five Australian jurisdictions (i.e. the Commonwealth, New South Wales, Northern Territory, Tasmania and Victoria) protect ritual confessions to clerics through a priest-penitent privilege section(s) in their Evidence Act(s). The Commonwealth Act applies to the High Court, Federal Court and the Federal Family Court (Middleton, 1995). However, the law reform commission of Queensland and Western Australia have rejected the application of a priest-penitent privilege into their Evidence Acts (Note 2). The wording of the priest-penitent privilege sections are a dichotomy: privileges given to the penitent and privileges given to the priest. The New South Wales jurisdiction contains a section in the professional communications privilege; which could cover the communications between the confider and cleric (Note 3).

\section{Priest Penitent Privilege}

Whilst they do have some things in common, the priest penitent privilege sections are distinct and have two different wordings that exist for quite distinct reasons. However, in both cases; the confession would need to be formal or ritual (Maybe, 2006). As used in the statutes, the term 'confession' must be interpreted as per its common law meaning and in those terms, a confession disclosed to a cleric means a ritual confession (Note 4).

Justice Crisp, in R v Lynch (Note 4) may have left the issue open in terms that the statutes may go further than protecting ritual confessions (Maybe, 2006). This may extend to protecting confessions not in ritual form, but as a spiritual end (Maybe, 2006). Whilst the question has not been tried since, a confession could be as informal as discussing spiritual matters with a cleric, nor does it need to be in ritual format (Maybe, 2006). Neither case law nor statutes have given specific examples of what would be covered. However, it appears a confession under the catholic religion would be covered (Note 5). Whilst the statutes refer to clerics (i.e. Christian religion), they endeavour to cover all churches and religious denominations (Note 6).

\subsection{For Society}

The privilege belongs to the penitent (i.e. member of society) in the Evidence Acts for Victoria and the Northern territory. This prevents clerics from what has been said in confidence. However, the privilege can be waivered with the consent of the penitent. For clerics asked to give evidence about communique in confidence under the section, unless the penitent has given their consent for the information to be disclosed, the cleric must claim the privilege on behalf of the penitent (Maybe, 2006). It's unclear what kind of relief the penitent could claim if the cleric failed to claim privilege as the information would already be disclosed (Maybe, 2006). It appears the section does not apply to former clerics (Maybe, 2006). This may have little significance as clerics are deemed members in many churches irrespective of their responsibilities or lack thereof. However, relevance may occur if the cleric left due to disciplinary action or personal reasons (Maybe, 2006).

\subsection{For Religion}

The privilege belongs to the cleric in the Evidence Acts of the Commonwealth, New South Wales and Tasmania. It would be abnormal if the privilege belonged to the confider and not the confidant (McNicol, 1992: 318).

The Acts define religious confession as:

'Confession made by a person to a member of the clergy in the member's professional capacity according to the ritual of the church or religious denomination concerned' (Note 7; Maybe, 2006).

A common argument against such a privilege is that it discriminates against religions without any form of ritual confession ((McNicol, 1992). Noting, that the privilege; belongs to current and former clerics and cannot be waived by consent from the penitent (Maybe, 2006). Whilst the penitent's wishes may be irrelevant, the privilege is not absolute because clerics are entitled, not obliged to refuse divulging subject matter from religious confessions (Note 8). Furthermore, a cleric can refuse to disclose if a confession was made or not (Note 9).

\section{New Privileges}

Two new privileges were added to the New South Wales Evidence Act in 1972. They were:

1. A professional communications privilege

2. A privilege for councillors of sexual assault victims (Note 10). For less formal conversations with a cleric, the professional communications privilege may provide protection for such communications; within New South Wales.

Confidential communications within a professional relationship are covered by the professional communications privilege. If a court thinks a relationship fits the definition, the privilege may be granted (Maybe, 2006). However, it does not just automatically apply as the court must exercise discretion and be satisfied that the given 
evidence has a likelihood of harm towards the protected confider and outweighs the allure of the evidence given (Note 11).

The professional limitations privilege is weighted by their consent and belongs to the confider (Note 12). The intent of the privilege protects the confider and holds no regard to the type or class of relationships (Note 13). Furthermore, there are no restrictions or obligations on particular professions with respect to confiders (Note 14). On its own initiative, the court can prevent evidence being given or on application from the confider and/or confidant (Maybe, 2006). Neither the confider and/or confidant need to be parties to the court proceedings (Note 15). Further power of the court allows it to make ancillary orders that reduce harm and allow the confidant to give evidence (Note 16).

Whilst the scope remains uncertain, the professional communications privilege potential applies to many different professions (Maybe, 2006). Such professions that could be covered include: accountants, counsellors, doctors, nurses, physio-therapists, social workers, therapists and private investigators (Odgers, 2004: 492). It is worth noting that it has been shown to apply to journalists (Odgers, 2004: 501; Note 17). However, application will be made on a case-by-case basis until it is determined exactly which professions and which communications will be covered by the privilege (Maybe, 2006). For communications not covered by the priest-penitent privilege, the professional communications privilege may cover counselling or other less formal discussions with clerics (Note 18). The penitent holds the privilege and any harm towards the cleric are not considered to be relevant. However, harm to the penitent if the indication was disclosed would need to be demonstrated for the privilege to apply (Maybe, 2006).

\section{Case Law}

Because they do not specifically deal with the privilege in their Evidence Acts, case law applies in Queensland, South Australia and Western Australia. The literature indicates a commonly held view that under case law, there is no privilege for clerics or penitents (Maybe, 2006). However, this view has not been tested due to the fact that the jurisdictions in Australia that do not have the privilege in their statute have not had cases in relation to the priest penitent privilege (Maybe, 2006).

\section{Australia's Contemporary Statutes}

Only one of the three cases was covered by modern statutes, R v Hay (Note 19); where specifically a cleric refused to testify. The other two cases, Norman Shaw v Norman Shaw (Note 20) and R v Griffin (Note 21) did not involve ritual confessions. If they did not involve ritual confession, then Australia's modern statutes would not have given the cleric the right of refusal on giving evidence under the priest-penitent privilege. Furthermore, the conversations may have been covered by the professional communications privilege if they had taken place in New South Wales (Maybe, 2006).

In R v Hay (Note 19), if the cleric had been in a Commonwealth, New South Wales or Tasmanian Court, he would not have had to disclose who he received the watch from because disclosure would have revealed the fact(s) and the content of the confession (Note 22; Maybe, 2006). These three cases are not conclusive as to the application, existence or not of the privilege. Therefore, clerics should assume that the privilege does not exist at common law, even though one could argue it has not been properly determined (Maybe, 2006).

\subsection{State Law and Religion}

The evidence acts of the Northern Territory and Victoria do not protect clerics under the priest penitent privilege. Nor does it add to the protection that 'church' law already gives penitents. Without the penitent's permission, the statute(s) prevent the cleric from revealing discussions that were conducted in the form of a ritual confession (Note 23). Churches not covered by the statute do not always enforce their clerics from not disclosing discussions that are confession like (Maybe, 2006).

\subsection{Held in Contempt}

Confidential conversations between clerics and a member of society under the professional communications privilege could be deemed that the privilege if applied is discriminatory in nature. It could be relevant to confessions made to a cleric in a professional capacity but not in a ritual setting (Note 18). A cleric would have to give evidence, if the privilege was waivered by the penitent (Note 24). Catholic priests would still not be able to disclose communications disclosed in the form of a ritual confession, even if the section was applied (Note 25). A cleric could be bound to give evidence if not covered by the privilege. Refusal to give evidence could be held to be in contempt of court with punishments ranging from fines to imprisonment (Note 18). 


\section{Conclusion}

In Australia, at case law; there does not appear to be a clearly recognised privilege for clerics and/or penitents. Through statute, the privilege has been implemented to cure the situation in five jurisdictions. Because the statutory provisions only apply to ritual confessions they only cover communications with clerics on a small scale which makes their usefulness limited. Whilst religion and the court system have a valuable part to play in society, the current situation could be deemed discriminatory and create conflict between, and damage to both institutions.

The professional communications privilege could have a broad function, is non-discriminatory and because of this; is best to serve Australia's multi-faith and multi-cultural society. More would be required to ensure Catholic priests would not be disadvantaged by the application of the privilege. Courts would need to consider a provision that determines if a cleric is under obligation not to divulge any communications. Further consideration would need to be given to Anglican clerics who can only reveal communications based on consent from the penitent. This would be specifically applicable if the individual asking for the confession to be disclosed was other than the penitent.

\section{References}

Maybe, R. (2006). The Priest-Penitent Privilege in Australia and its Consequences. Retrieved April 24, 2013, from http://elaw.murdoch.edu.au/archives/issues.2006/2/elaw_Renae\%20Mabey\%20Priest $\% 20$ Penitant $\% 20$ Privilege.pdf

McNicol, S. (1992). Law of Privilege. Sydney: Law Book Co.

Middleton, T. (1995). Privileges under the Evidence Act 1995 (Cth). Queensland Law Society Journal, 25(4), 349.

Odgers, S. (2004). Uniform Evidence Law (6th ed.). Pyrmont, NSW: Law Book Co.

Waight, P., \& Williams, B. (2002). Evidence Commentary and Materials (6th ed.). Sydney: Law Book Co.

\section{Notes}

Note 1. Broad v Pitt (1828) 172 ER 528, 528.

Note 2. Queensland Law Reform Commission Protection of Statements to Religiously Ordained Officials, Report 41(Queensland: the Commission, 1991), Queensland Law Reform Commission Review of the Uniform Evidence Acts, Report 60 (Queensland: The commission, 1995), Law Reform Commission of Western Australia, Professional Privilege for Confidential Communications, Report 90 (Western Australia: the Commission, 1993).

Note 3. New South Wales Legislative Council debates 22 October 1997: 1130.

Note 4. R v Lynch [1954] Tas SR 47, 48.

Note 5. Queensland Law Reform Commission Protection of Statements to Religiously Ordained Officials, Report 41(Queensland: the Commission, 1991), 4.

Note 6. Queensland Law Reform Commission Protection of Statements to Religiously Ordained Officials, Report 41(Queensland: the Commission, 1991), 5.

Note 7. S. 127(4) Evidence Act 1995 (Cth).

Note 8. Queensland Law Reform Commission, Protection of Statements to Religiously Ordained Officials, Report 41(Queensland: the Commission, 1991), 8.

Note 9. New South Wales Legislative Council Debates, 21 November 1989, 12807-12808.

Note 10. Evidence Amendment (Confidential Communications) Act 1997 (NSW).

Note 11. S. 126B (3), Evidence Act 1995 (NSW).

Note 12. S. 126C, Evidence Act 1995 (NSW).

Note 13. New South Wales Attorney Generals Department, Protecting Confidential Communications from Disclosure in Court Proceedings, Discussion paper (New South Wales June 1996), paras 4.9-4.11.

Note 14. New South Wales legislative Council debates 22 October 1997, 1122.

Note 15. S. 12B, (2) Evidence Act 1995 (New South Wales).

Note 16. S. 126D, Evidence Act 1995 (New South Wales). 
Note 17. NRMA v John Fairfax [2002] NSWSC 563.

Note 18. New South Wales Legislative Council Debates 22 October 1997, 1130 per Reverend Hon FJ Nile.

Note 19. R v Hay (1860) 175 ER 933.

Note 20. Normanshaw v Normanshaw (1893) 69 TL 468.

Note 21. R v Griffin (1853) 6 Cox CC 219.

Note 22. S. 127, Evidence Act 1995 (Cth) (NSW), 2000 (TAS).

Note 23. S. 12, Evidence Act 2005 (NT), S. 28 Evidence Act 1959 (VIC).

Note 24. S. 126C, Evidence Act 1995 (New South Wales).

Note 25. Canons 989 the Canon Law Society of Great Britain and Ireland (1995). The Canon Law Letter and Spirit, (London: Geoffrey Chapman, 1995), 535.

\section{Copyrights}

Copyright for this article is retained by the author(s), with first publication rights granted to the journal.

This is an open-access article distributed under the terms and conditions of the Creative Commons Attribution license (http://creativecommons.org/licenses/by/3.0/). 